\title{
Towards the sustainable use of granite powder waste for manufacturing of cementitious composites
}

\author{
Adrian Chajec ${ }^{1, *}$ \\ ${ }^{1}$ Wrocław University of Science and Technology, Faculty of Civil Engineering, pl. Wyspiańskiego 37 \\ 50-370 Wrocław, Poland
}

\begin{abstract}
The article is devoted to the description of the current state of knowledge about the possibilities of sustainable use of granite powder waste for manufacturing of cementitious composites. Granite powder waste is waste material resulting from the treatment of granite stone. In dry form, it is harmful to the environment and causes its degradation. One way to reduce its harmful effects is to use it for the sustainable production of cement composites and to use it as supplementary cementitious material (SCM). The results of researches carried out so far related to the impact of granite powder waste on the properties of fresh and hardened cementitious mixes are described. These results were compared and research gaps related to these studies were indicated. In summary, conclusions have been pointed out that indicate that granite powder waste can potentially be used as supplementary cementitious material, but comprehensive, comprehensive research related to this additive should also be carried out.
\end{abstract}

\section{Introduction}

Cementitious composites are one of the most widely used building materials in civil engineering industry. According to [1] from around the world the production and consumption of cement are constantly increasing. It should be emphasized that due to the very high $\mathrm{CO}_{2}$ emissions during its production and hydration, cement is one of the most environmental-impact building materials. In addition, storage of this hazardous material is very difficult [2-4]. The material characteristics of cement make it also dangerous, as it can cause pneumococcus or cancer [5,6]. All these elements mean that for several decades materials have been sought that can reduce the amount of cement used. These types of materials are called supplementary cementitious materials (SCM's). The most popular materials of this type include fly ash, limestone or marble powder [7-13].

Fly ash is a material formed as a result of burning fossil fuels. Nevertheless, in the case of fly ash, its significantly increasing consumption caused that this material ceased to be perceived as waste, and became a product whose price has increased significantly in recent years. This fact is further compounded by restrictions on the reduction of fossil fuel

\footnotetext{
* Corresponding author: adrian.chajec@pwr.edu.pl
} 
consumption and $\mathrm{CO}_{2}$ emissions by this industry. All these elements cause that more ecological materials, which are often waste, are being sought in order to use them in sustainable production of cementitious composites. Raw materials used for this purpose are powders: limestone, marble or granite. While the addition of limestone or marble powders is well researched by researchers, granite powder is still poorly studied and there is a lack of comprehensive research on this material.

Granite powder granulation depends on the process resulting in and is characterized by two basic types. The first type can be sourced from cutting granite rocks (90\% grains 0 $0.2 \mathrm{~mm}$ ). The second type can be sourced from crushing granite rocks (90\% of grains with a size of $0-1.0 \mathrm{~mm})$. The Figure 1 shows the processing process of granite rocks, which results in a granite powder waste.

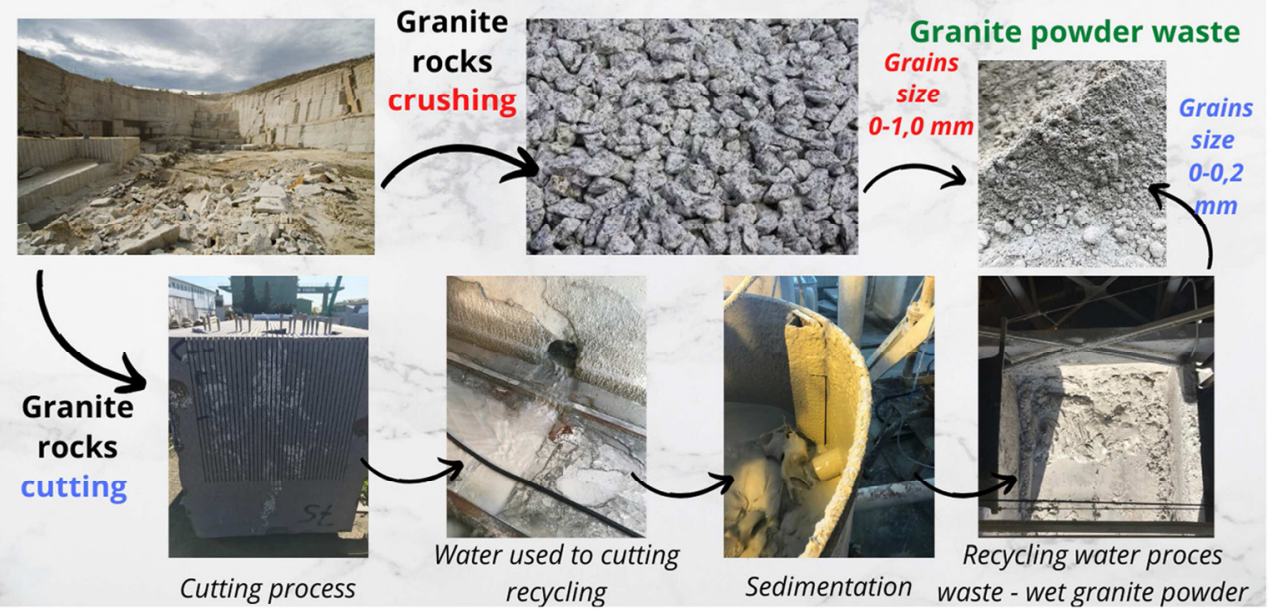

Fig. 1. Granite rocks processing, which result is granite powder waste.

Unfortunately, but the current lack of use of granite powder in any industry on a significant scale, caused that the deposits of this material increased enormously. This problem has been further compounded by the rapid development of Polish granite processing companies. All these elements have created a huge environmental problem. Growing deposits of granite powder waste due to the lack of its use and incompetent recycling policy, are already causing environmental degradation (dusting of plants, penetration of granite powder into water, change in $\mathrm{pH}$ of agricultural soils, landslides). All these negative aspects meant that researchers from around the world began to look for the possible use of granite powder for the mass production of various types of materials [14][18][19]. Figure 2 presents a graph of the change in the number of published articles on granite powder in recent years. 


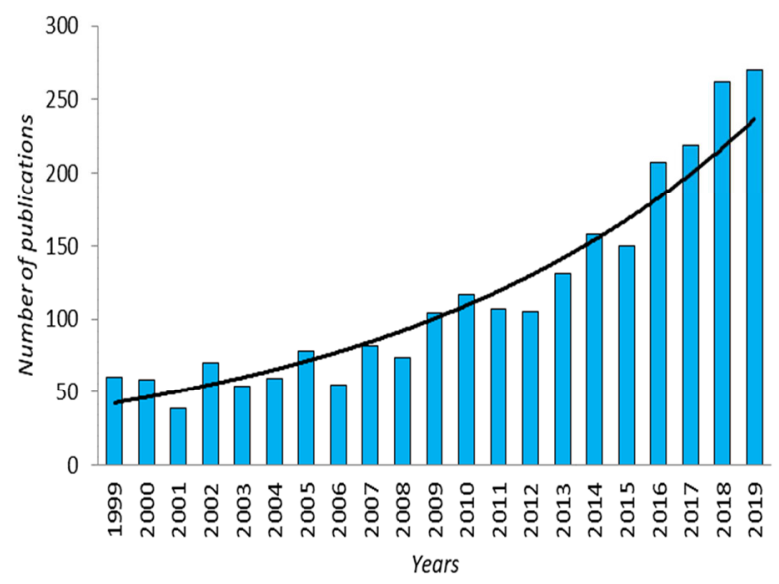

Fig. 2. Number of publication related with granite powder in last 10 years (data from ScienceDirect, Elsevier, date of search:20.10.2019r.).

One of the key example of this type solution is the use of granite powder as SCM. Considering the above, the article presents a literature review on the topic of using granite powder waste in the production of cementitious composites. The properties of the granite powder waste are described in comparison to other commonly used additives for cementitious mixtures, and attention is paid to the impact of granite powder waste on the properties of fresh and hardened cementitious mix. The aim of the article is also to investigate the potential of using granite powder waste as supplementary cementitious materials and to get acquainted with the experiences of researchers dealing with granite powder waste investigating.

\section{Selected properties of granite powder waste}

As mentioned in the introduction the granite powder is waste resulting from the processing of granite rocks (crushing or cutting). The chemical composition of this material depends on its origin (in different parts of the world granite has different proportions of chemical compounds present), however, it can be determined that granite powder is generally characterized by chemical compounds: $\mathrm{SiO}_{2}: 50-80 \% \mathrm{Al}_{2} \mathrm{O}_{3}: 10-20 \% \mathrm{CaO}: 5-15 \% \mathrm{~K}_{2} \mathrm{O}: 2-$ $5 \% \mathrm{Fe}_{2} \mathrm{O}_{3}: 3-8 \%$ and others: $<2 \%$. Table 1 present comparing of basic chemical and physical properties of the most commonly used SCM's.

Table 1. Selected chemical and physical properties of granite powder waste in comparison with cement and other commonly used supplementary cementitious materials (SCMs).

\begin{tabular}{|c|c|c|c|c|c|}
\hline $\begin{array}{c}\text { Chemical } \\
\text { compound }\end{array}$ & $\begin{array}{c}\text { Cement } \\
\text { CEM I [7, } \\
20]\end{array}$ & $\begin{array}{c}\text { Siliceous } \\
\text { fly ash [2, } \\
5,6]\end{array}$ & $\begin{array}{c}\text { Marble } \\
\text { powder [9- } \\
11],[21]\end{array}$ & $\begin{array}{c}\text { Limestone } \\
\text { powder [22, } \\
23]\end{array}$ & $\begin{array}{c}\text { Granite powder } \\
{[16,21,24]}\end{array}$ \\
\hline- & \multicolumn{7}{|c|}{ Chemical properties } \\
\hline \multicolumn{7}{|c|}{ Com } \\
\hline $\mathrm{SiO}_{2}$ & $20-22$ & $47-52$ & $3-10$ & $10-15$ & $50-80$ \\
\hline $\mathrm{Al}_{2} \mathrm{O}_{3}$ & $3-5$ & $20-29$ & $<1$ & $2-5$ & $10-20$ \\
\hline $\mathrm{Fe}_{2} \mathrm{O}_{3}$ & $3-5$ & $5-9$ & $<1$ & $1-3$ & $3-8$ \\
\hline $\mathrm{CaO}$ & $55-80$ & $3-6$ & $40-60$ & $40-50$ & $5-15$ \\
\hline
\end{tabular}




\begin{tabular}{|c|c|c|c|c|c|}
\hline $\mathrm{MgO}$ & $1-3$ & $2-5$ & $5-20$ & $1-3$ & $2-5$ \\
\hline $\mathrm{SO}_{3}$ & $2-5$ & $<1$ & $<1$ & $<1$ & $<1$ \\
\hline $\mathrm{Na}_{2} \mathrm{O}$ & $<1,0$ & $<1,5$ & $<1$ & $<1$ & $2-3$ \\
\hline $\mathrm{K}_{2} \mathrm{O}$ & $<1,0$ & $2-3$ & $<1$ & $<1$ & 2,5 \\
\hline \multicolumn{7}{|c|}{ Physical properties } \\
\hline $\begin{array}{c}\text { Blaine specific } \\
\text { surface area }\left[\mathrm{cm}^{2} / \mathrm{g}\right]\end{array}$ & $3500-4500$ & $3500-4500$ & $3200-4000$ & $7500-8500$ & $3500-4500$ \\
\hline
\end{tabular}

It can be seen that the chemical properties of supplementary cementitious materials are varied and different from the chemical properties of cement. Nevertheless, proper physical cement and SCM's are similar to each other.

The microstructure of granite powder is well known and was determined based on images from scanning electron microscopy (SEM). Researchers [2], [15] noticed that the appearance, shape and size of granite powder grains is similar to cement, so in morphological terms it is ideally suited to replace it in cementitious mixes.

\section{Properties of fresh cementitious mixes modified by granite powder waste}

There are many research hypotheses regarding the effects of SCMs on the properties of fresh cementitious mixes. However, in the case of mineral powders, they usually do not significantly change the properties of the modified mix compared to the reference mix. This hypothesis is also confirmed with regard to the effect of granite powder on the properties of fresh cement mix. The table 2 presents the results of state of the art correlated with research on the effect of granite powder addition on the properties of fresh cementitious mix.

Table 2. Effect of granite powder addition on properties of fresh cementitious mixes.

\begin{tabular}{|c|c|c|c|c|c|}
\hline Investigated by & $\begin{array}{l}\text { Slump } \\
\text { flow }\end{array}$ & $\begin{array}{c}\text { Setting time - } \\
\text { initial }\end{array}$ & $\begin{array}{l}\text { Setting time - } \\
\text { finish }\end{array}$ & Air content & Density \\
\hline $\begin{array}{c}\text { Shamsabadi et al. } \\
{[25]}\end{array}$ & $\begin{array}{c}\text { No } \\
\text { significance } \\
\text { change }\end{array}$ & \multirow{3}{*}{ Not investigated } & \multirow{7}{*}{ Not investigated } & \multirow{8}{*}{ Not investigated } & $\begin{array}{l}\text { Lower density } \\
\text { as the additive } \\
\text { increases }\end{array}$ \\
\hline $\begin{array}{l}\text { Nepomuceno et } \\
\text { al. [16] }\end{array}$ & More dense & & & & \multirow{7}{*}{$\begin{array}{c}\text { Not } \\
\text { investigated }\end{array}$} \\
\hline Hunger et al. [22] & More dense & & & & \\
\hline Singh et al. [26] & More dense & $\begin{array}{c}\text { No significance } \\
\text { change }\end{array}$ & & & \\
\hline Singh et al. [27] & More dense & \multirow{3}{*}{ Not investigated } & & & \\
\hline Gupta et al. [28] & $\begin{array}{c}\text { No } \\
\text { significance } \\
\text { change }\end{array}$ & & & & \\
\hline Sadek et al. [21] & $\begin{array}{c}\text { No } \\
\text { significance } \\
\text { change }\end{array}$ & & & & \\
\hline Medina et al. [29] & $\begin{array}{c}\text { Not } \\
\text { investigated }\end{array}$ & $\begin{array}{l}\text { Lower initial } \\
\text { time }\end{array}$ & $\begin{array}{l}\text { Lower finish } \\
\text { time }\end{array}$ & & \\
\hline
\end{tabular}


Analysing Table 2, it should be stated that granite powder has been increasingly tested in recent years. However, these studies usually concern the same properties, and in addition the results obtained by individual authors are varied. There are also many research gaps that should be filled to assess the possibility of using granite powder as supplementary cementitious materials.

\section{Properties of hardened cementitious mixes modified by granite powder waste}

The most important property of cement composites are mechanical properties. Mechanical properties determine the durability of elements made of cement composites. It is therefore intended that during the analysis of whether a given material can be seen as SCM, its impact on the properties of hardened cementitious mixes be controlled. Table 3 shows a literature review of the properties of hardened cementitious mixes modified by granite powder additive.

Table 3. Effect of granite powder addition on properties of hardened cementitious mixes.

\begin{tabular}{|c|c|c|c|c|c|c|}
\hline $\begin{array}{c}\text { Investigated } \\
\text { by }\end{array}$ & $\begin{array}{l}\text { Compressive } \\
\text { strength }\end{array}$ & $\begin{array}{c}\text { Bending } \\
\text { tensile } \\
\text { strength }\end{array}$ & $\begin{array}{c}\text { Water } \\
\text { absorption }\end{array}$ & Porosity & $\begin{array}{c}\text { Adhesion } \\
\text { test }\end{array}$ & $\begin{array}{l}\text { Abrasion } \\
\text { resistance }\end{array}$ \\
\hline $\begin{array}{c}\text { Shamabadi et } \\
\text { al. [25] }\end{array}$ & Decreases & Decreases & $\begin{array}{c}\text { Not } \\
\text { investigated }\end{array}$ & \multirow{7}{*}{$\begin{array}{c}\text { Not } \\
\text { investigated }\end{array}$} & $\begin{array}{c}\text { Not } \\
\text { investigated }\end{array}$ & Not investigated \\
\hline $\begin{array}{c}\text { Gupta et al. } \\
{[28]}\end{array}$ & $\begin{array}{c}\text { No } \\
\text { significance } \\
\text { change }\end{array}$ & $\begin{array}{c}\text { No } \\
\text { significance } \\
\text { change }\end{array}$ & $\begin{array}{c}\text { No } \\
\text { significance } \\
\text { change }\end{array}$ & & Increases & $\begin{array}{c}\text { No significance } \\
\text { change }\end{array}$ \\
\hline $\begin{array}{l}\text { Manikandam } \\
\text { et al. [30] }\end{array}$ & Increases & Increases & $\begin{array}{c}\text { No } \\
\text { significance } \\
\text { change } \\
\end{array}$ & & & \\
\hline Gao et al. [2] & Decreases & \multirow{2}{*}{$\begin{array}{c}\text { Not } \\
\text { investigated }\end{array}$} & \multirow{8}{*}{$\begin{array}{c}\text { Not } \\
\text { investigated }\end{array}$} & & investigated & Not investigated \\
\hline $\begin{array}{c}\text { Hunger et al. } \\
{[22]}\end{array}$ & Increases & & & & & \\
\hline $\begin{array}{l}\text { Singh et al. } \\
{[26]}\end{array}$ & $\begin{array}{c}\text { No } \\
\text { significance } \\
\text { change }\end{array}$ & Increases & & & Increases & $\begin{array}{c}\text { No significance } \\
\text { change }\end{array}$ \\
\hline $\begin{array}{c}\text { Al- } \\
\text { Hamaiedeh et } \\
\text { al. [31] }\end{array}$ & Increases & $\begin{array}{c}\text { Not } \\
\text { investigated }\end{array}$ & & & \multirow{6}{*}{$\begin{array}{c}\text { Not } \\
\text { investigated }\end{array}$} & \multirow{5}{*}{ Not investigated } \\
\hline $\begin{array}{c}\text { Medina et al. } \\
{[29]}\end{array}$ & Decreases & Decreases & & $\begin{array}{c}\text { No } \\
\text { significance } \\
\text { change }\end{array}$ & & \\
\hline $\begin{array}{c}\text { Marmol et al. } \\
{[32]}\end{array}$ & \multirow{3}{*}{$\begin{array}{l}\text { No } \\
\text { significance } \\
\text { change }\end{array}$} & $\begin{array}{c}\text { Not } \\
\text { investigated }\end{array}$ & & \multirow{4}{*}{$\begin{array}{c}\text { Not } \\
\text { investigated }\end{array}$} & & \\
\hline $\begin{array}{c}\text { Ramos et al. } \\
{[17]}\end{array}$ & & $\begin{array}{c}\text { No } \\
\text { significance } \\
\text { change } \\
\end{array}$ & & & & \\
\hline Li et al. [33] & & \multirow{2}{*}{$\begin{array}{c}\text { Not } \\
\text { investigated }\end{array}$} & & & & \\
\hline $\begin{array}{c}\text { Sadek et al. } \\
{[21]}\end{array}$ & Increases & & Decreases & & & $\begin{array}{c}\text { No significance } \\
\text { change }\end{array}$ \\
\hline
\end{tabular}

Analysing Table 3, it should be noted that among the selected properties of hardened cementitious mixes only compressive strength was studied by all researchers. The results obtained by researchers differ significantly, which means that there is still a large research gap in this topic. It should be noted that the other studies were rudimentary and do not 
allow the conclusion that granite powder can be used as supplementary cementitious material.

\section{Economic aspect of using supplementary cementitious materials in cementitious mixes}

When analysing the possibility of using the material as an additive to cementitious mixes, one should check the profitability of this solution. For this purpose, an economic analysis was performed, which compared the prices of cement blended with the most commonly using SCM's mixtures [Tab.4]. The average price of cement $\mathrm{uc}_{\text {cement }}=74.66 € /$ ton, average price siliceous fly ash $\mathrm{uc}_{\text {fly ash }}=34.25 € /$ ton, average price marble powder $\mathrm{uc}_{\mathrm{mp}}=250.41$ $€ /$ ton, average price limestone powder $\mathrm{uc}_{\mathrm{lp}}=27.27 € /$ ton, average price granite powder $\mathrm{uc}_{\mathrm{gp}}$ $=5,15 € /$ ton. The costs of other ingredients of cementitious mixes and transport costs were excluded. The cost of blended cement with SCM's was calculated for three different sizes of SCM's additions: 10, 20 and 30\% along with a simultaneous reduction in the amount of cement. In order to compare the results, the ECR coefficient [-] was introduced into the reference mortar.

$$
E C R=\frac{C_{\text {mixes }}}{C_{\text {reference }}} \times 100 \%[\%]
$$

Table 4. Economic analysis of costs cement blended with the most commonly using SCM's.

\begin{tabular}{|c|c|c|c|c|c|c|c|c|c|c|}
\hline & Ingredient & Mixes & $\begin{array}{c}\text { Cement } \\
\text { ratio }\end{array}$ & $\begin{array}{l}\text { SCM } \\
\text { ratio } \\
\end{array}$ & $\mathbf{u c}_{\text {cement }}$ & $\mathbf{u c}_{\mathrm{SCM}}$ & $\mathbf{c}_{\text {cement }}$ & $\mathbf{c}_{\mathrm{SCM}}$ & $\mathbf{c}_{\text {mixes }}$ & ECR \\
\hline \multicolumn{5}{|c|}{$[-]$} & \multicolumn{2}{|c|}{$€ /$ ton } & \multicolumn{3}{|c|}{$€$} & {$[-]$} \\
\hline 1 & Cement & Reference & 1 & 0 & \multirow{13}{*}{74.66} & - & 74.66 & 0.00 & 74.66 & $100 \%$ \\
\hline 2 & \multirow{3}{*}{$\begin{array}{l}\text { Siliceous } \\
\text { fly ash }\end{array}$} & $\begin{array}{l}10 \% \\
\text { SCM }\end{array}$ & 0.9 & 0.1 & & \multirow{3}{*}{34.25} & 67.19 & 3.43 & 70.62 & $95 \%$ \\
\hline 3 & & $\begin{array}{l}20 \% \\
\text { SCM } \\
\end{array}$ & 0.8 & 0.2 & & & 59.73 & 6.85 & 66.58 & $89 \%$ \\
\hline 4 & & $\begin{array}{l}30 \% \\
\text { SCM }\end{array}$ & 0.7 & 0.3 & & & 52.26 & 10.28 & 62.54 & $84 \%$ \\
\hline 5 & \multirow{3}{*}{$\begin{array}{l}\text { Marble } \\
\text { powder }\end{array}$} & $\begin{array}{l}10 \% \\
\text { SCM } \\
\end{array}$ & 0.9 & 0.1 & & \multirow{3}{*}{250.41} & 67.19 & 25.04 & 92.24 & $124 \%$ \\
\hline 6 & & $\begin{array}{l}20 \% \\
\text { SCM }\end{array}$ & 0.8 & 0.2 & & & 59.73 & 50.08 & 109.81 & $147 \%$ \\
\hline 7 & & $\begin{array}{l}30 \% \\
\text { SCM }\end{array}$ & 0.7 & 0.3 & & & 52.26 & 75.12 & 127.39 & $171 \%$ \\
\hline 8 & \multirow{3}{*}{$\begin{array}{l}\text { Limestone } \\
\text { powder }\end{array}$} & $\begin{array}{l}10 \% \\
\text { SCM } \\
\end{array}$ & 0.9 & 0.1 & & \multirow{3}{*}{27.27} & 67.19 & 2.73 & 69.92 & $94 \%$ \\
\hline 9 & & $\begin{array}{l}20 \% \\
\text { SCM }\end{array}$ & 0.8 & 0.2 & & & 59.73 & 5.45 & 65.18 & $87 \%$ \\
\hline 10 & & $\begin{array}{l}30 \% \\
\text { SCM } \\
\end{array}$ & 0.7 & 0.3 & & & 52.26 & 8.18 & 60.44 & $81 \%$ \\
\hline 11 & \multirow{3}{*}{$\begin{array}{l}\text { Granite } \\
\text { powder }\end{array}$} & $\begin{array}{l}10 \% \\
\text { SCM }\end{array}$ & 0.9 & 0.1 & & \multirow{3}{*}{5.15} & 67.19 & 0.52 & 67.71 & $91 \%$ \\
\hline 12 & & $\begin{array}{l}20 \% \\
\text { SCM }\end{array}$ & 0.8 & 0.2 & & & 59.73 & 1.03 & 60.76 & $81 \%$ \\
\hline 13 & & $\begin{array}{l}30 \% \\
\text { SCM } \\
\end{array}$ & 0.7 & 0.3 & & & 52.26 & 1.55 & 53.81 & $72 \%$ \\
\hline
\end{tabular}

Summing up Table 4, it should be stated that granite powder has the greatest potential to be used as an SCM in economic terms. Reducing the amount of cement with granite powder can reduce its cost by up to $28 \%$ compared to the reference mix. In addition, granite flour in 
economic terms significantly more favourably affects the price of cementitious mixes than other SCM's listed in Table 4.

\section{Conclusions}

The article is devoted to the description of the current state of knowledge about the possibilities of sustainable use of granite powder waste for manufacturing of cementitious composites. The results of researches carried out so far related to the impact of granite powder waste on the properties of fresh and hardened cementitious mixes are described. Based on the analysis carried out, the following conclusions were drawn:

- granite powder waste has significant potential associated with reducing the amount of cement in cementitious mixes and reducing the amount of $\mathrm{CO} 2$ emissions formed during the cement hydration reaction,

- there are a lot of research gaps regarding the properties of fresh cementitious mixes modified by granite powder, which should be filled due to the huge potential of using granite powder waste as SCM,

- granite powder waste is the most cost-effective additive to cementitious mixes, which does not significantly change their mechanical properties,

In order to determine the true potential of granite powder waste as a supplementary cementitious material (SCM), it is planned to carry out in the future such tests as: the possibility of a pozzolanic reaction, changes in the properties of fresh cementitious mixes, changes in the cement hydration process caused by the addition of granite powder waste.

\section{References}

1. Ł. Sadowski, M. Piechówka-Mielnik, T. Widziszowski, A. Gardynik, and S. Mackiewicz, J. Clean. Prod. 212, 727-740 (2019)

2. X. Gao, B. Yuan, Q. L. Yu, and H. J. H. Brouwers, J. Clean. Prod. 164, 410-419 (2017)

3. M. B. Ali, R. Saidur, and M. S. Hossain, Renew. Sust. Energ. Rev 15 (5), 2252-2261 (2011)

4. N. A. Madlool, R. Saidur, M. S. Hossain, and N. A. Rahim, Renew. Sust. Energ. Rev 15 (4), 2042-2060 (2011)

5. T. Y. Huang, P. T. Chiueh, and S. L. Lo, Resour. Conserv. Recycl. 123, 255-260 (2017)

6. M. Ahmaruzzaman, Progress in Energy and Combustion Science 36 (3), 327-363, (2010)

7. S. P. Pandey and R. L. Sharma, Cem. Concr. Res. 30 (1), 19-23 (2000)

8. C. Y. Lee, H. K. Lee, and K. M. Lee, Cem. Concr. Res. 33 (3), 425-431 (2003)

9. N. Toubal Seghir, M. Mellas, Ł. Sadowski, and A. Żak, J. Clean. Prod. 183, 858-868 (2018)

10. N. Toubal Seghir, M. Mellas, Ł. Sadowski, A. Krolicka, A. Żak, and K. Ostrowski, Sustainability 11 (8), 2215 (2019)

11. N. Toubal Seghir, M. Mellas, Ł. Sadowski, A. Krolicka, and A. Żak, JOM 71 (3), 1002-1015 (2019)

12. M. Dobiszewska, Kompozyty cementowe $z$ dodatkiem pyłu bazaltowego. (Bydgoszcz 2019) (in Polish) 
13. M. Dobiszewska, J. Mater. Educ. 39 (6), 133-156 (2017)

14. B. Jeyaprabha, G. Elangovan, and P. Prakash, Mater. Struct. Constr. 50 (1), 1-14 (2017)

15. H. Yazici, M. Y. Yardimci, H. Yiğiter, S. Aydin, and S. Türkel, Cem. Concr. Compos. 32 (8), 639-648 (2010)

16. M. Nepomuceno, L. Oliveira, and S. M. R. Lopes, Constr. Build. Mater. 26 (1), 317326 (2012)

17. T. Ramos, A. M. Matos, B. Schmidt, J. Rio, and J. Sousa-Coutinho, Constr. Build. Mater. 47, 1001-1009 (2013)

18. K. Ostrowski et al. Materials (Basel). 11 (8), 1372 (2018)

19. K. Ostrowski, D. Stefaniuk, Ł. Sadowski, K. Krzywiński, M. Gicala, and M. Różańska, Constr. Build. Mater. 238, 117794 (2020)

20. A. A. Aliabdo, A. E. M. Abd Elmoaty, and E. M. Auda, Constr. Build. Mater. 50, 2841 (2014)

21. D. M. Sadek, M. M. El-Attar, and H. A. Ali, J. Clean. Prod. 121, 19-32 (2016)

22. M. Hunger and H. J. H. Brouwers, Natural Stone Waste Powders Applied to SCC Mix Design (2008)

23. M. Kępniak, P. Woyciechowski, P. Łukowski, J. Kuziak, and R. Kobyłka, Materials (Basel) 12 (10), (2019)

24. T. R. Naik, S. S. Singh, and M. M. Hossain, Cem. Concr. Res. 24 (2), 303-312 (1994)

25. E. Asadi Shamsabadi, M. Ghalehnovi, J. de Brito, and A. Khodabakhshian, Appl. Sci. 8 (10), 1808 (2018)

26. S. Singh, R. Nagar, and V. Agrawal, J. Clean. Prod. 127, 172-182 (2016)

27. S. Singh, R. Nagar, V. Agrawal, A. Rana, and A. Tiwari, J. Clean. Prod. 116, 223-235 (2016)

28. L. K. Gupta and A. K. Vyas, Constr. Build. Mater. 191, 155-164 (2018)

29. G. Medina, I. F. Sáez del Bosque, M. Frías, M. I. Sánchez de Rojas, and C. Medina, J. Clean. Prod. 148, 467-476 (2017)

30. M. Manikandan and T. Felixkala, Int. J. Civ. Eng. Technol. 8 (4), 2246-2254 (2017)

31. H. D. Al-Hamaiedeh and W. H. Khushefati, J. Appl. Sci. 13 (3), 444-450 (2013)

32. I. Mármol, P. Ballester, S. Cerro, G. Monrós, J. Morales, and L. Sánchez, Cem. Concr. Compos. 32 (8), 617-622 (2010)

33. L. G. Li, Y. M. Wang, Y. P. Tan, and A. K. H. Kwan, Powder Technol. 342, 388-396 (2019) 